\title{
Surgical Management of Bladder Cancer During First Month of COVID-19 Outbreak: Lessons Learned Across Italy
}

Carmen Maccagnano ( $\sim$ carmen.maccagnano@gmail.com )

Azienda Socio Sanitaria Lariana

Lorenzo Rocchini

Fondazione IRCCS Ca'Granda, Ospedale Maggiore Policlinico

Emanuele Montanari

Fondazione IRCCS Ca'Granda, Ospedale Maggiore Policlinico, University of Milan

Giario Natale Conti

Azienda Socio Sanitaria Lariana

Roberto Contieri

Istituto Clinico Humanitas, IRCCS Clinical and Research Hospital

Kadi-Anna Bryan

Rogue Valley Urology

Rodolfo Hurle

Istituto Clinico Humanitas, IRCCS Clinical and Research Hospital

\section{Research Article}

Keywords: COVID-19, Urology, Pandemic, Outbreak, Bladder Cancer, Non-Muscle Invasive Bladder Cancer, Trans-Urethral Resection of Bladder Tumor, Cystectomy, Haematuria.

Posted Date: May 21st, 2020

DOI: https://doi.org/10.21203/rs.3.rs-29496/v1

License: (a) (1) This work is licensed under a Creative Commons Attribution 4.0 International License. Read Full License 


\section{Abstract}

\section{Objectives:}

Real-life overview of bladder cancer (BC) surgical management in Italy during the first month of COVID-19 pandemic (March 2020) with head to head comparison of the data from March 2019, considered "usual activity" period. The aim is to confront performance of Academic Centers (AC) vs Non Academic Centers (NAC) as well as non-COVID Centers (nCC) and COVID Centers (CC).

\section{Patients and methods:}

During April 2020, an e-mail survey was sent to 32 Sections of Urology across Italy. It contained 14 multiple-choice questions focused on activities during March 2019 and March 2020. Statistical analysis was performed using IBM SPSS Statistics (v26) software.

\section{Results}

28 centers answered to survey. AC and NAC showed statistically significant differences (chi-square test $p<0.05)$ about number of physicians assigned to Covid wards $(p=0.001)$, Trans-Urethral Resection of Bladder Tumour (TURBT) $(p=0.046)$ and cystectomies $(p=0.037)$ performed in March $2020(p=0.037)$. In 2020, AC performed more surgical procedures compared to NAC. In 2019, AC had more procedures per Operating Block (OB) $(p=0.015)$ and greater number of emergent Trans-Urethral Resections (TUR) $(p=0.014)$, while NAC had more TURBTs.

CC had more patients ( $p t s)$ both evaluated for gross hematuria $(p=0.017)$ and requiring haemostatic Trans-Urethral Resection (hTUR) in 2019. In $2020 \mathrm{nCC}$ had more surgeries per OB ( $p=0.001)$, TURBTs $(p=0.030)$ and cystectomies $(p=0.034)$ than CC.

\section{Conclusion}

The COVID-19 pandemic represents an important challenge for cancer centers, in the context of an extremely dynamic clinical and political situation which requires maximum flexibility to be appropriately managed.

\section{Introduction}

On March $11^{\text {th }}, 2020$ the World Health Organization (WHO) declared the disease caused by the novel Coronavirus SARS-COV-2 a global pandemic. This resulted in profound social, economic and political repercussions worldwide [1]. In Italy alone, the period from January $30^{\text {th }}$ to April $11^{\text {st }}$ saw 147,577 cases and 18,851 confirmed COVID-19-related deaths [2]. The Italian Government was the first in Europe to progressively adopt a series of restrictive social distancing measures, with the aim of both reducing the spread of the virus and promoting the "flattening of the curve", until enacting a nationwide quarantine on 
March, $9^{\text {th }}$ [3-8]. As a result, the management of pts with cancer, including those affected by genitourinary malignancies, have been gradually altered.

A significant decrease of elective surgical procedures as well as a prioritization of the oncological interventions, whenever possible, in order to preserve health care resources and staff, was observed. Moreover, a significant shortage of health care personnel, which has been calculated around $30 \%$, was noted; this is partially due to hospital-acquired infections, where health care personnel account for around $41 \%$ of nosocomial SARS-COV2 [9]. China, Italy, and Spain have all reported that $3.8 \%$ to $10 \%$ of confirmed COVID-19-positive cases were healthcare workers [10-18].

Moreover, familial responsibilities and school closings have to be considered as additional reasons for staff shortage [19].

At the time of the explosion of the pandemic in Western Countries, in the first weeks of March, there were no institutional urology guidelines to help prioritize procedures, and it was likely that this resulted in an "all or none situation". Day by day, urologists decided what surgeries had to be done immediately, and what could be delayed for months [20]. Consequently, several International and National Scientific Societies have recently published recommendations about the management of malignancies during outbreak.

Nevertheless, the impact of such recommendations on urologic practice needs to be investigated.

The first aim of the present study is presenting a real life overview about the surgical management of BC, in different centers across Italy during the first month of SARS-COV-2 outbreak in March 2020, comparing data from the same period in 2019 , considered "usual activity".

The secondary aim is comparing the differences between $\mathrm{AC}$ and $\mathrm{NAC}$ and between $\mathrm{nCC}$ and $\mathrm{CC}$.

\section{Materials And Methods}

During the first week of April 2020, our group sent an e-mail survey containing 14 multiple -choice questions, focused on surgical activity related to BC carried out in March 2019 and March 2020 to 32 Divisions of Urology across Italy (see appendix 1). We also queried medical staffing at these facilities: the number of Urologists (including resident physicians) at each institution and the number of urologists dedicated to COVID wards for each institute.

Four centers ( $2 \mathrm{AC}$ and $2 \mathrm{NAC}$ ) did not answer. Thus, we based the results on the information received by 28 Centers.

The Urology Sections involved in the study had the following characteristics: 15/28 (53.6\%) were AC; $11 / 28$ (39.3\%) were in the Lombardy Region (epicenter of the Italian epidemic); $24 / 28$ (85,7\%) were located in hospitals equipped with an emergency room (ER); $14 / 28(50 \%)$ were located in the north of Italy and 7/28 (25\%) in the south; 4/28 (14,3\%) were COVID-free nCC during the outbreak. nCC were 
defined as hospitals where only pts with negative nasopharyngeal swab and negative chest CTs were admitted.

Statistical analysis of the data was performed using IBM SPSS Statistics (v26) software.

We evaluated the differences between AC and NAC with regards to the number of cystectomies, TURBTs, OB dedicated to urology and number of surgical procedures during March 2019 and March 2020. Our aim is to compare the surgical management of $\mathrm{BC}$ in $\mathrm{AC}$ and NAC during the pandemic. We also tested the differences between nCC and CC, in order to verify the efficacy of "COVID-free approach" in the fight against the virus, and thinking about the eventual need of establishing additional nCCs in order to ameliorate the management of the uncertainty of next future linked to evolution of outbreak.

In the end, we compared our data with other studies using a Medline search of articles published between January 2020 up to April, 25 $5^{\text {th }}$; the key words were: "COVID-19", "Urology", "Pandemic", "Outbreak", "Bladder Cancer", "Non-Muscle Invasive Bladder Cancer", "Trans-Urethral Resection of Bladder Tumor", "Cystectomy", "Haematuria”.

\section{Results}

The data for AC and NAC are reported in table 1.

AC and NAC statistically differ (chi-square test) for the number of medical doctors Covid wards $(p=0.001)$, number of TURBT performed during pandemic period $(p=0,046)$ and number of cystectomies performed in march $2020(p=0,037)$ (table 2). The number of medical doctors was greater in AC, including residents. To note, during the pandemic, the number of surgical procedures were superior in terms of both TURBT and cystectomies in the AC. Considering the singular performance, $\mathrm{AC}$ differed for number of intervention performed per OB $(p=0,015)$ and number of hTUR $(p=0,014)$, in favor of 2019 (table 2$)$. On the other hand, NAC, did not show any statistically differences in term of surgical performance comparing march 2019 with march 2020, except for the number of TURBT, which was higher in march 2019 (table 3).

There were 4 nCC: $2 / 14(14,3 \%)$ among AC and 2/13 (15,4\%) among NAC.

Regarding $\mathrm{nCC}$ versus $\mathrm{CC}$, a significant statistical difference in the presence of ER in the hospital in favor of CC $(p=0.000)$, as well as number of pts evaluated for hematuria $(p=0,017)$ and undergone hTUR in march $2019(p=0,004)$ were observed. These data are also supported by the fact that in the nCC there were 3 centers $(3 / 4,75 \%)$ without the ER.

Conversely, the performance of $\mathrm{nCC}$ was better than $\mathrm{CC}$ in terms of numbers of operation performed per OB during pandemic month ( $p=0,001)$, number of TURBT cancer during March $2020(p=0,030)$, number of cystectomies performed during March $2020(p=0,034)$ (table 4).

No differences between 2019 and 2020 emerged, considering surgical activity of CC only: number of OB dedicated to urology $(p=0,24)$; number of operation performed per OB $(p=0,1)$; number of TURBT $(p=0,54)$; 
number of cystectomy $(p=0,116)$ and number of hTUR $(p=0,107)$. The only parameter that statistically differed $(p=0,022)$ consisted in number of pts evaluated in ER for hematuria (higher in march 2019), suggesting that, probably, pts were being referred less frequently to the ER for concerns regarding COVID19 infection.

On the other hand, in nCC group no difference was appreciated in terms of surgical performance and number of pts evaluated for hematuria $(p=0,250)$ or undergone hTUR $(p=0,250)$ between 2019 and 2020 . However, we should consider the limits of these data: there are only $4 \mathrm{nCC}$ and 2 of these have not ER.

We also explored the differences among CC - AC centers and nCC - AC centers, reporting no statistical differences except for the number of TURBT performed in march $2020(p=0,042)$ that seemed superior in nCC - AC group. However, we should consider the nCC-AC were only 2.

Regression analysis did not show any predictive value (PV) in term of AC and NAC superiority probably due to small sample size. On the other hand, considering $\mathrm{nCC}$ and $\mathrm{CC}$ centers, regression showed a PV of surgical performance the presence of ER in the institute. To note, these data have to be considered as small and preliminary and more extensive studies are needed.

\section{Discussion}

When the COVID-19 pandemic expanded into Western Countries during the last weeks of February 2020, there were no guidelines to aid in prioritizing surgical procedures. Day by day, urologists decided independently what interventions needed to be performed immediately, and what could be delayed safely for weeks and possibly months [20]. Since then, several International and National Scientific Societies have published recommendations about the management of malignancies during SARS-COV-2 pandemic (table 5).

Unfortunately, these recommendations are based on the limited data available in the literature and are subject to continually changing. Currently, their impact on urologic practice is unknown as the consequences of these delays remain speculative.

\section{Management of Bladder Cancer in Academic and Non-Academic Centers}

The first month of the COVID-19 outbreak was characterized by the need to provide assistance to overwhelming number of infected pts and, simultaneously, treat all non-deferrable conditions, both oncological. As result, several facilities had to retrain or re-assign personnel to Covid-Related Activities (CRA), even if this was outside of their original designation.

In our study, both AC and NAC retained $70 \%$ of their urological staff for "usual" urological activities and only $30 \%$ were reassigned for CRA. In a few NAC up to $50 \%$ of people were reassigned to CRA and this can be partly due to the reduced personnel usually working in these centers, who have been employed in CRA during March 2020. 
The increase in the activity of NAC may be explained by patient seeking care at the nearest medical institution in a time with strict travel limitations [22]. As a matter of fact, in Italy, pts routinely move from the Southern regions to the North to address medical needs.

In our study the amount of urologic OB remained the same during both 2019 and 2020, in all centers. In both AC and NAC groups we observed a decrease of numbers of TURBTs in March 2020, compared to March 2019. Moreover, NAC group have shown a mild decrease of the number of surgical procedures per OB during 2020. This is likely due to performing only emergent oncological surgeries where a time delay may be life threatening. According to international recommendations, pre-operative planning for complex surgical procedures has to take into consideration patient functional status, hospital infrastructure and local COVID-19 burden (table 6). Additionally, while cancer surgeries are not considered emergent it is also not elective and should be prioritized as discussed by Ueda et al [19].

Altogether, these data demonstrate the significant efforts were made by Italian urologists to proceed with urgent procedures despite COVID-19 outbreak.

Curiously, Campi et al. have recently found that approximately two thirds of pts with genitourinary malignancies do not require high-priority surgery and $25 \%$ of pts requiring high-priority surgery is considered at high perioperative risk. This increasing risk is partially defined by the immunocompromised state cancer-related, which lead higher susceptibility to infectious disease, compared to general population [14]. During this pandemic, the risk of COVID-19 related complications, including Intensive Care Unit (ICU) admissions, has been calculated to be 3.5 folds higher than usual [22].

On the other hand, Wang and Coll have underlined the risk for cancer pts who do not receive adequate and timely medical treatments during an outbreak, resulting in a potentially dangerous delay of urooncologic surgeries, with a final impact on the short and intermediate-term progression and mortality rates [17][22][23].

In fact, regarding the management of $\mathrm{BC}$, which represents $3.0 \%$ of all cancers, we observed a reduction of the number of TURBT in all centers during the pandemic [14]. To note, up to around $50 \%$ of NAC have performed $<5$ TURBT, compared to $0 \%$ in 2019. These data probably may have an impact on BC stage migration in the near future, with an increasing of the admissions to ER for hematuria or pts presenting with Muscle-Invasive Bladder Cancer (MIBC) at time of diagnosis.

The Scientific Societies indicate the possibility of deferring TURBT, according to risk of progression and recurrence, as indicated in table 5. Unfortunately, we did not collect detailed data about TURBT; thus, we cannot comment on this specific issue.

On the other hand, the number of cystectomies has generally increased in all centers, even as the percentage of NAC which performed 1-5 cystectomies have increased from $7 \%$ to $38 \%$, compared to AC where there was an increase from 33 up to $46 \%$. Conversely, the percentage of centers with number of cystectomies $>5$ remained the same in AC while it fell from $30.8 \%$ to $7.7 \%$ in NAC. 
Campi and coll. have reported cystectomy as second procedure of major surgery executed during COVID19 outbreak (11.7\% of all urological procedures) [14].

These data are in agreement with International Scientific Societies recommendations, which indicate that cystectomy should not be postponed, as MIBC is considered a high risk of progression and rapid distant metastasis (table 5).

ER admissions due to hematuria have decreased during COVID-19 outbreak, especially in NAC.

All the hospitals have performed hemostatic TUR in $<50 \%$ of cases during both 2019 and 2020 . During 2019 more centers performed hemostatic TUR in up to 50\% of cases. All these data can be justified by the general reduction of ER admissions because of non-Covid reasons.

In conclusion, we can say that in Covid-era the surgical performances related to $\mathrm{BC}$ have decreased; this impact has been greater in the NAC.

\section{Management of Bladder Cancer in COVID- and non-COVID Centers}

The rapid increasing number of pts affected by the SARS-COV2 virus have exerted significant pressure on the healthcare systems of Western countries, with an emphasis on maintaining emergency and essential services. The need to dedicate major economic, infrastructural and health care resources to assist SARSCOV2 pts during the first weeks of the outbreak resulted in a rapid reallocation of staff, wards and equipment from several medical disciplines not primarily involved in the management of COVID-19 pts [15][20]. Consequently, there was the disruption of training and education opportunities for junior medical staff [24-26].

In Italy, two alternative solutions have been found:

1. Transferring surgical activity for non-COVID pts to nCC specifically dedicated to manage noninfected pts, with strict admission and monitoring criteria to identify infected individuals, reducing exposure of staff and the public to the virus and allowing for surgical procedures [19][20]. These centers adopted strict organizational and functional criteria, reported in table 7.

2. Designating Covid Centers (CCs) thereby converting the wards of the hospital to COVID-dedicated units and limiting surgical cases as personnel and resources are reassigned. Unfortunately, these urgent measures have resulted in several cancellations or surgical delays, and urologists are required to triage and proceed with only the most essential or critical procedures. The outpatient clinics have been also cancelled or changed to telephone or video consultations. For example, Naspro and Coll. have recently reported that in Papa Giovanni XXIII Hospital in Bergamo, in the epicenter of pandemic, during the 10 days of the first cases of SARS-COV2, two-thirds of the hospital beds were occupied by pts with COVID-19. Within 2 weeks, urological surgical volume was reduced to $30 \%$, then $15 \%$ and then totally halted as of March 19. With the progression of the outbreak, all non-emergent urology surgeries were cancelled with few exceptions for emergent and some urgent cases [27]. 
In a recent editorial Prof. Montorsi described that at the San Raffaele Hospital in Milan, volunteer young physicians became staff members within the COVID-19 patient units and 6 urologists worked in the units in 8-hour shifts, every day, 7 days a week. The chiefs of the various surgical units regularly met every week and created a priority list identifying pts who will be operated on during the next 7 days [28].

Although there is no official data, it has been reported that a new health migration is underway, with a flow of pts moving from high endemic areas to areas where they can obtain adequate care [29]. In some case the transfer has not only been intra-regional but also inter-regional.

This structural reorganization has to be considered as relevant because there is no reliable provision on the duration of emergency and its economic and social consequences [15]

Additionally, we have to be aware that in the next months we will live with the presence of the virus among the population. In this context, a rapid rationalization of resources becomes mandatory in order to ensure continuity of healthcare for Covid-free pts [29].

Moreover, thinking about urology, we have to consider that some authors have identified the viral RNA, antigens, antibodies and viral components in the urine and hypothesized both the potential route of urine transmission and a challenge to the urinary system. In fact, various urogenital illnesses can be induced by virus, and may exacerbate and even cause life-threatening conditions without careful surveillance. On the other hand, pts affected with chronic urinary diseases may have increased susceptibility to COVID-19 and such underlying comorbidities may result in a poor prognosis without adequate cures [30].

In our investigation we found four nCC: two in the North and two in the Center; there were no pts with SARS-COV2 as there was no ER in the most of them (3/4) or the ancient architectural structure resulted in the designation of a COVID-free pavilions (1/4) [31].

Additionally, the center with Covid-free pavillions was academic, with more than 40 urologists, including residents. This organization allowed for the residency program to proceed without interruptions to teaching program [25][26].

As a matter of fact, we have seen that the number of urological operating session has been substantially the same in 2019 and 2020 even if the CC showed a decrease of about $17 \%$ of the number of urological operating session during pandemic.

As expected, in nCC the number of urological procedures was almost the same if compared with the same period of 2019 , in CC this number declines as expected.

This could be partly due to the fact that $\mathrm{CC}$ are limited to performing a single procedure per $\mathrm{OB}$ according to aforementioned guidelines.

The number of TURBT have decreased in CC; these data are consistent with the previous considerations. 
On the other hands, the total number of cystectomies have remained the same in 2019 and 2020 but additional centers have performed this operations in 2020, assisting to a sort of distribution of cystectomies across Italy, probably linked to the emergency.

In conclusion, the correct prioritization of the surgical procedures represents the corner stone of the management of urological malignancies during a pandemic. In general, an accurate triage for possible COVID-19 symptoms performed both by telephone at home before hospitalization and at the time of hospitalization is advisable in all pts candidate to surgery. Instructions in order to facilitate smooth discharge and home recuperation, should be given during hospitalization. The discharging of pts should minimize the risk of readmission, with reduction or rescheduling post-discharge controls. with implementation of an adequate system of telemonitoring [32].

Additionally, implementation of non-COVID surgical areas in CC or creation of hospital networks in order to refer pts needing non-deferrable procedures to nCC should be strongly recommended, as said by Ficarra and Coll.

In nCC, the organization could be the same as well as in the usual period and this could be fundamental in the management of oncological pts, as aforementioned.

\section{What we should expect in the next months?}

The improvement of management of pts may be concrete if we have more COVID-dedicated hospitals. This leads to appropriate cure both for COVID and COVID-free pts who are affected with urologic cancer and should not have a delay in definitive management.

We should expect a significant $\mathrm{BC}$ stage migration, with an increasing number of pts with adverse pathology and prognosis, as well as an increasing number of early cystectomies in younger people.

\section{Conclusions}

The COVID-19 pandemic represents an important challenge and learning opportunity for cancer centers, in the context of an extremely dynamic clinical and political situation which requires maximum flexibility to be appropriately faced.

Our real-life data from several centers across Italy, despite limited, may represent an important insight into the $\mathrm{BC}$ surgical management in times of emergency, helping other urology centers in adapting their management strategies for the inflow of uro-oncologic pts in light of the expected reduction in resources caused by the COVID-19 pandemic. We finally believe that some of the solutions proposed to face the current emergency, if maintained, may optimize routine clinical practice even in standard health conditions.

\section{Declarations}




\section{AUTHORS' CONTRIBUTION}

Maccagnano: Project development; Data collection and management; Data analysis; Manuscript writing

Rocchini: Data analysis; Manuscript writing

Montanari: Manuscript editing

Conti: Manuscript editing

Contieri: Data collection and management

Bryan: Data analysis; Manuscript writing and editing

Hurle: Project development, Data analysis; Manuscript writing and editing

\section{COMPLIANCE OF ETHICAL STANDARDS}

Funding: none

Conflict of Interest: The authors declare that they have no conflict of interest.

Research involving Human Participants and/or Animals; Informed consent: The authors had permissions for both the use of survey and the publication of data by all the participants indicated in "Aknowledgements" sections.

\section{AKNOWLEDGEMENTS}

Davide Arcaniolo, MD. RTDA in Urology, Università degli Studi della Campania "L. Vanvitelli" - Naples, Italy.

Aldo Massimo Bocciardi, MD. Urology Unit, Niguarda Hospital, Milan, Italy.

Pierluigi Bove, MD. Professor of Urology. Urology Unit San Carlo di Nancy Hospital Rome - GVM Care and Research, Department of Surgery Tor Vergata, University of Rome. Rome, Italy.

Gian Maria Busetto, MD PhD. Department of Urology Sapienza Rome University, Policlinico Umberto I. Rome, Italy

Giulia Maria Castagna, MD. Section of Urology. ASST Melegnano e Martesana, Melegnano (Milan), Italy.

Renzo Colombo, MD. Department of Urology, IRCCS San Raffaele. Vita-Salute University, Milan, Italy.

Roberto Contieri, MD. Istituto Clinico Humanitas IRCCS, Clinical and Research Hospital. Rozzano (Milan), Italy.

Federico Dehò, MD. Unit of Urology; ASST Sette Laghi-Circolo e Fondazione Macchi Hospital, Varese, Italy. 
Paolo Fedelini, Md. Chairman of Urology. Department of Urology, A. Cardarelli Hospital, Naples, Italy.

Maria Consiglia Ferriero, Department of Experimental Clinical Oncology, Urology Unit, IRCCS Regina Elena National Cancer Institute, Rome, Italy.

Matteo Ferro, MD. Section of Urology. Istituto Oncologico Europeo (IEO), Milan, Italy.

Andrea Benedetto Galosi, MD, Chairman of Urology. Università Politecnica delle Marche, Ancona, Italy.

Vincenzo Giannone, MD. Section of Urology. Vito Fazzi Hospital, Lecce, Italy

Paolo Gontero, MD. Chairman Division of Urology Molinette Hospital, University of Torino School of Medicine, Department of Surgical Sciences. Torino, Italy.

Francesco Greco, MD. Section of Urology, Humanitas Gavazzeni, Bergamo, Italy.

Valerio lacovelli, MD. Urology Unit San Carlo di Nancy Hospital Rome - GVM Care and Research, Department of Surgery Tor Vergata University of Rome. Rome, Italy.

Alberto Lapini, MD. Department of Urology, University of Florence, University Hospital, Florence, Italy.

Giuseppe Lucarelli, MD, PhD, University of Bari, Department of Emergency and Organ Transplantation (DETO), Urology, Andrology and Kidney Transplantation Unit. Bari, Italy.

Michele Marchioni, M.D. Department of Medical, Oral and Biotechnological Sciences

Università degli Studi "G.d'Annunzio" - Chieti, Italy

Andrea Mari, MD. Department of Urology, University of Florence, University Hospital, Florence, Italy.

Bruno Mazzoccoli, MD. Section of Urology. ASM Matera. Matera, Italy.

Luciano Nava, MD. Division of Urology. Humanitas San Pio X - Milan, Italy.

Giovanni Petralia, MD. Urology Unit, Niguarda Hospital, Milan, Italy.

Paolo Pompa, MD. Section of Urology , Pierangeli Clinics, Pescara, Italy

Angelo Porreca, MD. Department of Urology, Abano Terme Policlinic, Abano Terme (PD), Italy.

Giorgio I. Russo, MD, PhD, University of Catania. Catania, Italy

Vincenzo Serretta, MD. Department of Surgical, Oncological and Oral Sciences, Section of Urology, University of Palermo, Palermo, Italy.

Francesco Soria, MD, FEBU. Division of Urology Molinette Hospital, University of Torino School of Medicine, Department of Surgical Sciences. Torino, Italy. 
Elena Strada, MD. Urology Unit, Niguarda Hospital, Milan, Italy.

Nazareno Suardi, MD, FEBU. Department of Urology, IRCCS Policlinico San Martino Hospital, University of Genova, Genova, Italy.

Paolo Viganò, MD. Urology Unit, Bassini Hospital, Cinisello Balsamo, Italy

Alberto Carlo Vismara, MD. Division of Urology. Humanitas Gavazzeni, Bergamo, Italy.

\section{References}

1. Sohrabi C,Alsafi Z, O'Neill N, et al. World Health Organization declares global emergency: A review of the 2019 novel coronavirus (COVID-19). Int J Surg 2020; 76:71-76.

2. https://who.sprinklr.com/region/euro/country/IT.

3. Sjödin H, Wilder-Smith, Osman S, et al. Only strict quarantine measures can curb the coronavirus disease (COVID-19) outbreak in Italy, 2020. Euro Surveill 2020; 25(13):pii=2000280. https://doi.org/10.2807/1560-7917.ES.2020.25.13.2000280.

4. Nacoti M, Ciocca A, Giupponi A, et al. At the epicenter of the Covid-19 pandemic and humanitarian crises in Italy: changing perspectives on preparation and mitigation. NEJM 2020. https://catalyst.nejm.org/doi/full/10.1056/CAT.20.0080).

5. Council of Ministers' Resolution, 31st January 2020 - "Declaration of a state of emergency due to health risk linked to the insurgence of pathologies deriving from transmissible viral agents"gazzettaufficiale.it/eli/id/2020/02/01/20A00737/sg.

6. Decree Law $n^{\circ} 6,23$ February 2020 - "Urgent measures to contain and manage the epidemiological emergency due to COVID-19".https://www.gazzettaufficiale.it/eli/id/2020/02/23/20G00020/sg.

7. http://www.salute.gov.it/portale/nuovocoronavirus/dettaglioFaqNuovoCoronavirus.jsp? lingua=italiano\&id=228\#11.

8. Shared protocol for the regulation of measures to contrast and contain the diffusion of COVID-19 virus in the workplace, 14 th March 2020.http://www.governo.it/sites/new.governo.it/files/protocollo_condiviso_20200314.pdf.

9. Ti LK,Ang LS, Foong TW, et al. What we do when a COVID-19 patient needs an operation: operating room preparation and guidance. Can J Anaesth. 2020 Mar 6. doi: 10.1007/s12630-020-01617-4.

10. http://weekly.chinacdc.cn/en/article/id/e53946e2-c6c4-41e9-9a9b- fea8db1a8f51

11. https://www.epicentro.iss.it/coronavirus/bollettino/Infografica_28marzo\%20ENG.pdf

12. Proietti S, Gaboardi F, Giusti G.Endourological Stone Management in the Era of the COVID-19. Eur Urol2020 Apr 14. pii: S0302-2838(20)30217-7. doi:10.1016/j.eururo.2020.03.042.

13. Damery S, Wilson S, Draper $\mathrm{H}$, et al. Will the NHS continue to function in an influenza pandemic? A survey of healthcare workers in the West Midlands, UK. BMC Public Health2009 May 14;9:142. doi: 10.1186/1471-2458-9-142. 
14. Campi R, Amparore D, Capitanio U, et al. Assessing the Burden of Nondeferrable Major Uro-oncologic Surgery to Guide Prioritisation Strategies During the COVID-19 Pandemic: Insights from Three Italian High-volume Referral Centres. Eur Urol2020 Apr 11. pii: S0302-2838(20)30229-3. doi: 10.1016/j.eururo.2020.03.054.

15. Ficarra V, Novara G, Abrate A, et al. Urology practice during COVID-19 pandemic. Minerva Urol Nefrol. 2020 Mar 23. doi: 10.23736/S0393-2249.20.03846-1.

16. Gillessen S, Powles T. Advice Regarding Systemic Therapy in Patients with Urological Cancers During the COVID-19 Pandemic. Eur Urol 2020 Apr 17. pii: S0302-2838(20)30201-3. doi: 10.1016/j.eururo.2020.03.026.

17. Stensland KD, Morgan TM, Moinzadeh A, et al. Considerations in the Triage of Urologic Surgeries During the COVID-19 Pandemic. Eur Urol 2020 Apr 9. pii: S0302-2838(20)30202-5. doi:

10.1016/j.eururo.2020.03.027.

18. American College of Surgeons. COVID-19: guidance for triage of non-emergent surgical procedures. facs.org/about-acs/covid-19/information-for-surgeons/triage

19. UedaM, Martins R, Hendrie PC, et al. Managing Cancer Care During the COVID-19 Pandemic: Agility and Collaboration Toward a Common Goal. J Natl Compr Canc Netw 2020 Mar 20:1-4. doi: 10.6004/jnccn.2020.7560.

20. Goldman HB, Haber GP. Recommendations for Tiered Stratification of Urological Surgery Urgency in the COVID-19 Era. J Urol 2020 Apr 21:101097JU0000000000001067. doi: $10.1097 /$ JU.0000000000001067.

21. Remuzzi A,Remuzzi G. COVID-19 and Italy: what next? Lancet 2020 Apr 11;395(10231):1225-1228. doi: 10.1016/S0140-6736(20)30627-9. Epub 2020 Mar 13.

22. Puliatti S, Eissa A, Eissa R, et al. COVID-19 and Urology: A Comprehensive Review of the Literature. BJUlnt 2020 Apr 6. doi: 10.1111/bju.15071.

23. Wang H,Zhang L. Risk of COVID-19 for patients with cancer. Lancet Oncol. 2020 Apr;21(4):e181. doi: 10.1016/S1470-2045(20)30149-2. Epub 2020 Mar 3.

24. Ho HC,Hughes T, Bozlu M, et al. What do urologists need to know: Diagnosis, treatment, and followup during COVID-19 pandemic. Turk J Urol. 2020 Apr 14. doi: 10.5152/tud.2020.20119.

25. GabrielsonAT, Kohn TP, Clifton MM. COVID-19 and the Urology Match: Perspectives and a Call to Action. J Urol 2020 Mar 31:101097JU0000000000001037. doi: 10.1097/JU.0000000000001037.

26. VargoE, Ali M, Henry F, Kmetz D, et al. Cleveland Clinic Akron General Urology Residency Program's COVID-19 Experience. Urology 2020 Apr 2. pii: S0090-4295(20)30341-1. doi: 10.1016/j.urology.2020.04.001.

27. Naspro R,Da Pozzo LF. Urology in the time of corona. Nat Rev Urol. 2020 Mar 23. doi: 10.1038/s41585-020-0312-1.

28. Montorsi F. We Should Not Ignore What Scientific Articles are Telling US: A Lesson from the Italian COVID-19 Experience. J Urol.2020 Apr 3:101097JU0000000000001069. doi: 
10.1097/JU.0000000000001069.

29. Leonardi R, Bellinzoni P, Broglia L, et al. Hospital care in Departments defined as Covid-free: A proposal for a safe hospitalization protecting healthcare professionals and patients not affected by Covid 19. Archiv Ital Urol Androl 2020; 92, 2DOI: 10.4081/aiua.2020.2

30. Wu ZS,Zhang ZQ, Wu S. Focus on the Crosstalk Between COVID-19 and Urogenital Systems. J Urol. 2020 Apr 3:101097JU0000000000001068. doi: 10.1097/JU.0000000000001068. [Epub ahead of print]

31. Campi R, Zeng G, Dasgupta P, 16 March 2020. https://www.bjuinternational.com/bjui-blog/covid-19collection-of-urology-papers/.

32. Simonato A, Giannarini G, Abrate A, et al. Pathways for urology patients during the COVID-19 pandemic. Minerva Urol Nefrol.2020 Mar 30. doi: 10.23736/S0393-2249.20.03861-8.

33. CinarP, Kubal T, Freifeld A, et al. Safety at the Time of the COVID-19 Pandemic: How to Keep our Oncology Patients and Healthcare Workers Safe. J Natl Compr Canc Netw 2020 Apr 15:1-6. doi: 10.6004/jnccn.2020.7572.

34. BrücherBLDM, Nigri G, Tinelli A, et al. COVID-19: Pandemic surgery guidance. 4open 2020; 3. https://doi.org/10.1051/fopen/2020002Published online10 April 2020

35. Liang W,Guan W, Chen R, et al. Cancer patients in SARS-CoV-2 infection: a nationwide analysis in China. Lancet Oncol 2020 ;21(3):335-337. doi: 10.1016/S1470-2045(20)30096-6. Epub 2020 Feb 14.

36. Yu J, Ouyang W, Chua MLK, Xie C. SARS-CoV-2 Transmission in Patients With Cancer at a Tertiary Care Hospital in Wuhan, China. JAMA Oncol.2020 Mar 25. doi: 10.1001/jamaoncol.2020.0980.

37. https://www.cdc.gov.

\section{Tables}

TABLE 1: Academic Vs Non-Academic Centers 


\begin{tabular}{|c|c|c|c|c|}
\hline & ACADEMIC & $\begin{array}{c}\text { NON } \\
\text { ACADEMIC }\end{array}$ & Number & $\mathbf{P}$ \\
\hline NUMBER & $15 / 28$ & $13 / 28$ & & \\
\hline $\begin{array}{l}\text { COVID FREE } \\
\text { YES } \\
\text { NO }\end{array}$ & $\begin{array}{c}2 / 15 \\
(13,3 \%) \\
13 / 15 \\
(86,7 \%) \\
\end{array}$ & $\begin{array}{c}2 / 13 \\
(15,4 \%) \\
11 / 13 \\
(84,6 \%) \\
\end{array}$ & $\begin{array}{c}4 / 28 \\
(14,3 \%) \\
24 / 28 \\
(85,7 \%) \\
\end{array}$ & 0,877 \\
\hline $\begin{array}{l}\text { EMERGENCY ROOM: } \\
\text { YES } \\
\text { NO }\end{array}$ & $\begin{array}{c}14 / 15 \\
(93,3 \%) \\
1 / 15(6,7 \%)\end{array}$ & $\begin{array}{c}10 / 13 \\
(76,9 \%) \\
3 / 13 \\
(23,1 \%) \\
\end{array}$ & $\begin{array}{c}24 / 28 \\
(85,7 \%) \\
4 / 28 \\
(14,3 \%) \\
\end{array}$ & 0,216 \\
\hline $\begin{array}{c}\text { STAFF: } \\
<10 \\
10-20 \\
>20\end{array}$ & $\begin{array}{c}1 / 15(6,7 \%) \\
7 / 15 \\
(46,7 \%) \\
7 / 15 \\
(46,7 \%)\end{array}$ & $\begin{array}{c}9 / 13 \\
(69,2 \%) \\
4 / 13 \\
(30,8 \%) \\
0 / 13\end{array}$ & $\begin{array}{c}10 / 28 \\
(35,7 \%) \\
11 / 28 \\
(39,3 \%) \\
7 / 28 \\
(25 \%) \\
\end{array}$ & 0,001 \\
\hline $\begin{array}{l}\text { MEDICAL DOCTORS EMPLOYED IN COVID WARDS DURING MARCH 2020: } \\
\qquad \begin{array}{c}<30 \% \\
30 \%-50 \% \\
>50 \%\end{array}\end{array}$ & $\begin{array}{c}13 / 15 \\
(86,7 \%) \\
2 / 15 \\
(13,3 \%) \\
0 / 15\end{array}$ & $\begin{array}{c}9 / 13 \\
(69,2 \%) \\
1 / 13(7,7 \%) \\
3 / 13 \\
(23,1 \%)\end{array}$ & $\begin{array}{c}22 / 28 \\
(78,6 \%) \\
3 / 28 \\
(10,7 \%) \\
3 / 28 \\
(10,7 \%) \\
\end{array}$ & 0,140 \\
\hline $\begin{array}{l}\text { NUMBER OF OPERATING SESSION, PER WEEK, DEDICATED TO UROLOGY DIVISION } \\
\text { DURING MARCH 2020: } \\
0 \\
1-2 \\
>2\end{array}$ & $\begin{array}{c} \\
\\
\\
1 / 15(6,7 \%) \\
1 / 15(6,7 \%) \\
13 / 15 \\
(86,7 \%)\end{array}$ & $\begin{array}{c}3 / 13 \\
(23,1 \%) \\
3 / 13 \\
(23,1 \%) \\
7 / 13 \\
(53,8 \%) \\
\end{array}$ & $\begin{array}{c}4 / 28 \\
(14,3 \%) \\
4 / 28 \\
(14,3 \%) \\
20 / 28 \\
(71,4 \%) \\
\end{array}$ & 0,159 \\
\hline $\begin{array}{l}\text { NUMBER OF OPERATING SESSION, PER WEEK, DEDICATED TO UROLOGY DIVISION } \\
\text { DURING MARCH 2019: } \\
0 \\
1-2 \\
>2\end{array}$ & $\begin{array}{c}0 / 15 \\
2 / 15 \\
(13,3 \%) \\
13 / 15 \\
(86,7 \%)\end{array}$ & $\begin{array}{c}0 / 13 \\
3 / 13 \\
(23,1 \%) \\
10 / 14 \\
(76,9 \%)\end{array}$ & $\begin{array}{c}0 / 28 \\
5 / 28 \\
(17,9 \%) \\
23 / 28 \\
(82,1 \%)\end{array}$ & 0,502 \\
\hline 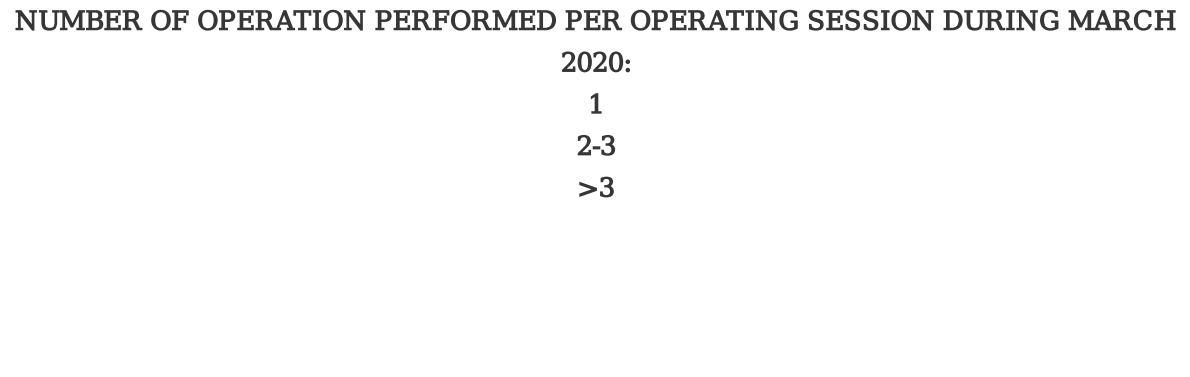 & $\begin{array}{c}1 / 15(6,7 \%) \\
10 / 15 \\
(66,7 \%) \\
4 / 15 \\
(26,7 \%)\end{array}$ & $\begin{array}{c}3 / 13 \\
(23,1 \%) \\
7 / 13 \\
(53,8 \%)\end{array}$ & $\begin{array}{c}4 / 28 \\
(14,3 \%) \\
17 / 28 \\
(60,7 \%)\end{array}$ & 0,464 \\
\hline
\end{tabular}




\begin{tabular}{|c|c|c|c|c|}
\hline & & $\begin{array}{c}3 / 13 \\
(23,1 \%)\end{array}$ & $\begin{array}{c}7 / 28 \\
(25 \%) \\
\end{array}$ & \\
\hline $\begin{array}{l}\text { NUMBER OF OPERATION PERFORMED PER OPERATING SESSION DURING MARCH } \\
\qquad \begin{array}{c}2019: \\
1 \\
2-3 \\
>3\end{array}\end{array}$ & $\begin{array}{c}1 / 15(6,7 \%) \\
9 / 15(60 \%) \\
5 / 15 \\
(33,3 \%)\end{array}$ & $\begin{array}{c}0 / 13 \\
9 / 13 \\
(69,2 \%) \\
4 / 13 \\
(30,8 \%)\end{array}$ & $\begin{array}{c}1 / 28 \\
(3,6 \%) \\
18 / 28 \\
(64,3 \%) \\
9 / 28 \\
(32,1 \%)\end{array}$ & 0,615 \\
\hline $\begin{array}{c}\text { NUMBER OF TRANS-URETHRAL RESECTION PERFORMED DURING MARCH 2020: } \\
<5 \\
5-15 \\
>15\end{array}$ & $\begin{array}{c} \\
\\
1 / 15(6,7 \%) \\
10 / 15 \\
(66,7 \%) \\
4 / 15 \\
(26,7 \%)\end{array}$ & $\begin{array}{c}6 / 13 \\
(46,2 \%) \\
4 / 13 \\
(30,8 \%) \\
3 / 13 \\
(23,1 \%)\end{array}$ & $\begin{array}{c}7 / 28 \\
(25 \%) \\
14 / 28 \\
(50 \%) \\
7 / 28 \\
(25 \%) \\
\end{array}$ & 0,046 \\
\hline $\begin{array}{l}\text { NUMBER OF TRANS-URETHRAL RESECTION PERFORMED DURING MARCH 2019: } \\
\qquad 5 \\
5-15 \\
>15\end{array}$ & $\begin{array}{c} \\
\\
1 / 15(6,7 \%) \\
5 / 15 \\
(33,3 \%) \\
9 / 15(60 \%)\end{array}$ & $\begin{array}{c}0 / 13 \\
6 / 13 \\
(46,2 \%) \\
7 / 13 \\
(53,8 \%)\end{array}$ & $\begin{array}{c}1 / 28 \\
(3,6 \%) \\
11 / 28 \\
(39,3 \%) \\
16 / 28 \\
(57,1 \%) \\
\end{array}$ & 0,548 \\
\hline $\begin{array}{c}\text { NUMBER OF CYSTECTOMY PERFORMED DURING MARCH 2020: } \\
0 \\
1-5 \\
>5\end{array}$ & $\begin{array}{c}2 / 15 \\
(13,3 \%) \\
7 / 15 \\
(46,7 \%) \\
6 / 15(40 \%)\end{array}$ & $\begin{array}{c}7 / 13 \\
(53,8 \%) \\
5 / 13 \\
(38,5 \%) \\
1 / 13(7,7 \%)\end{array}$ & $\begin{array}{c} \\
9 / 28 \\
(32,1 \%) \\
12 / 28 \\
(42,9 \%) \\
7 / 28 \\
(25 \%) \\
\end{array}$ & 0,037 \\
\hline $\begin{array}{c}\text { NUMBER OF CYSTECTOMY PERFORMED DURING MARCH 2019: } \\
0 \\
1-5 \\
>5\end{array}$ & $\begin{array}{c}4 / 15 \\
(26,7 \%) \\
5 / 15 \\
(33,3 \%) \\
6 / 15(40 \%)\end{array}$ & $\begin{array}{c}8 / 13 \\
(61,5 \%) \\
1 / 13(7,7 \%) \\
4 / 13 \\
(30,8 \%)\end{array}$ & $\begin{array}{c}12 / 28 \\
(42,9 \%) \\
6 / 28 \\
(21,4 \%) \\
10 / 28 \\
(35,7 \%)\end{array}$ & 0,118 \\
\hline 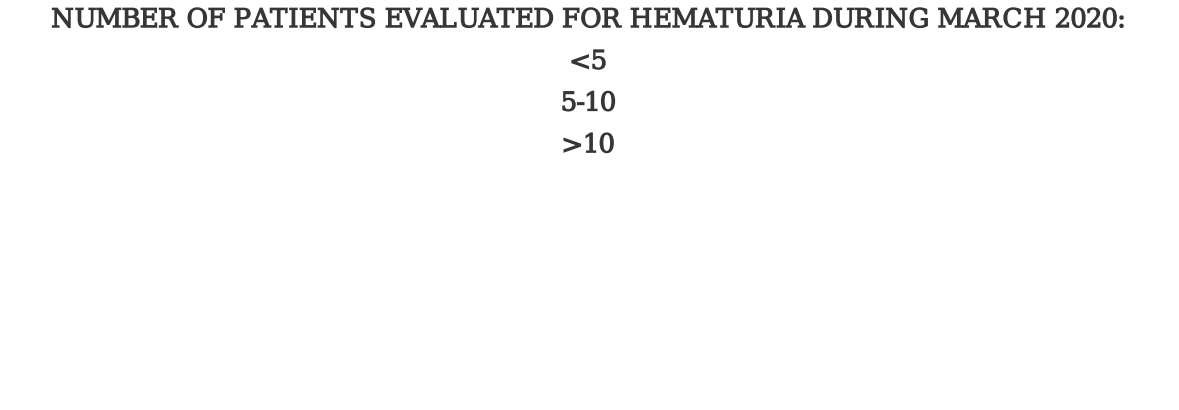 & $\begin{array}{c} \\
\\
5 / 15 \\
(33,3 \%) \\
4 / 15 \\
(26,7 \%) \\
6 / 15(40 \%)\end{array}$ & $\begin{array}{c}6 / 13 \\
(46,2 \%) \\
4 / 13 \\
(30,8 \%) \\
3 / 13 \\
(23,1 \%)\end{array}$ & $\begin{array}{c}11 / 28 \\
(39,3 \%) \\
8 / 28 \\
(28,6 \%) \\
9 / 28 \\
(32,1 \%)\end{array}$ & 0,621 \\
\hline
\end{tabular}




\begin{tabular}{|c|c|c|c|c|}
\hline 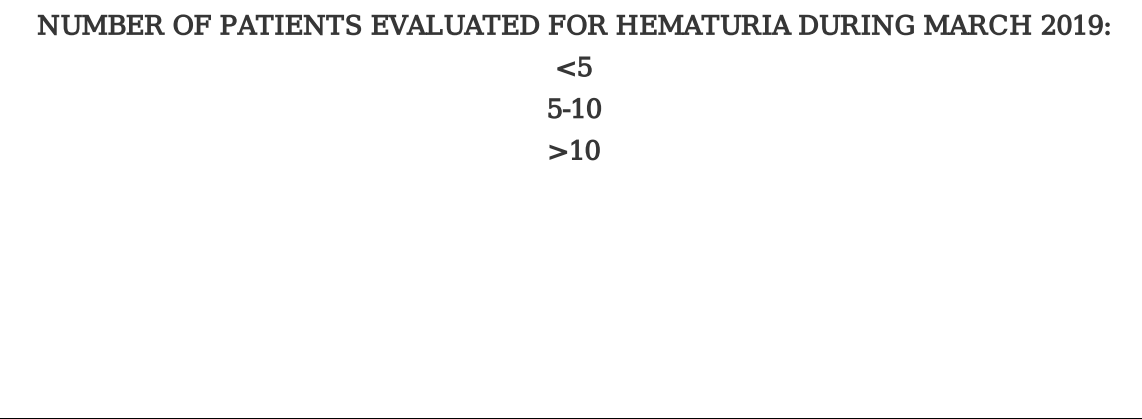 & $\begin{array}{l}3 / 15(20 \%) \\
3 / 15(20 \%) \\
9 / 15(60 \%)\end{array}$ & $\begin{array}{l}3 / 13 \\
(23,1 \%) \\
4 / 13 \\
(30,8 \%) \\
6 / 13 \\
(46,2 \%)\end{array}$ & $\begin{array}{c}6 / 28 \\
(21,4 \%) \\
7 / 28 \\
(25 \%) \\
15 / 28 \\
(53,6 \%)\end{array}$ & 0,740 \\
\hline $\begin{array}{l}\text { NUMBER OF PATIENTS UNDERGONE TO TUR FOR HEMOSTATIC/DIAGNOSTIC } \\
\qquad \begin{array}{c}\text { PURPOSE DURING MARCH 2020: } \\
0 \\
<50 \% \\
>50 \%\end{array}\end{array}$ & $\begin{array}{c} \\
\\
3 / 15(20 \%) \\
10 / 15 \\
(66,7 \%) \\
2 / 14 \\
(13,3 \%)\end{array}$ & $\begin{array}{l}6 / 13 \\
(46,2 \%) \\
5 / 13 \\
(38,5 \%) \\
2 / 13 \\
(15,4 \%) \\
\end{array}$ & $\begin{array}{c}9 / 28 \\
(32,1 \%) \\
15 / 28 \\
(53,6 \%) \\
4 / 28 \\
(14,3 \%) \\
\end{array}$ & 0,281 \\
\hline $\begin{array}{c}\text { NUMBER OF PATIENTS } \\
\text { UNDERGON TO TUR FOR HEMOSTATIC/DIAGNOSTIC PURPOSE DURING MARCH } \\
2019: \\
0 \\
<50 \% \\
>50 \%\end{array}$ & $\begin{array}{c}2 / 15 \\
(13,3 \%) \\
7 / 15 \\
(46,7 \%) \\
6 / 16(40 \%)\end{array}$ & $\begin{array}{c}3 / 13 \\
(23,1 \%) \\
7 / 13 \\
(53,8 \%) \\
3 / 13 \\
(23,1 \%)\end{array}$ & $\begin{array}{c}5 / 28 \\
(17,9 \%) \\
14 / 28 \\
(50 \%) \\
9 / 28 \\
(32,1 \%)\end{array}$ & 0,588 \\
\hline
\end{tabular}

TABLE 2. Academic Centers: Comparison of 2019 and 2020 activity 


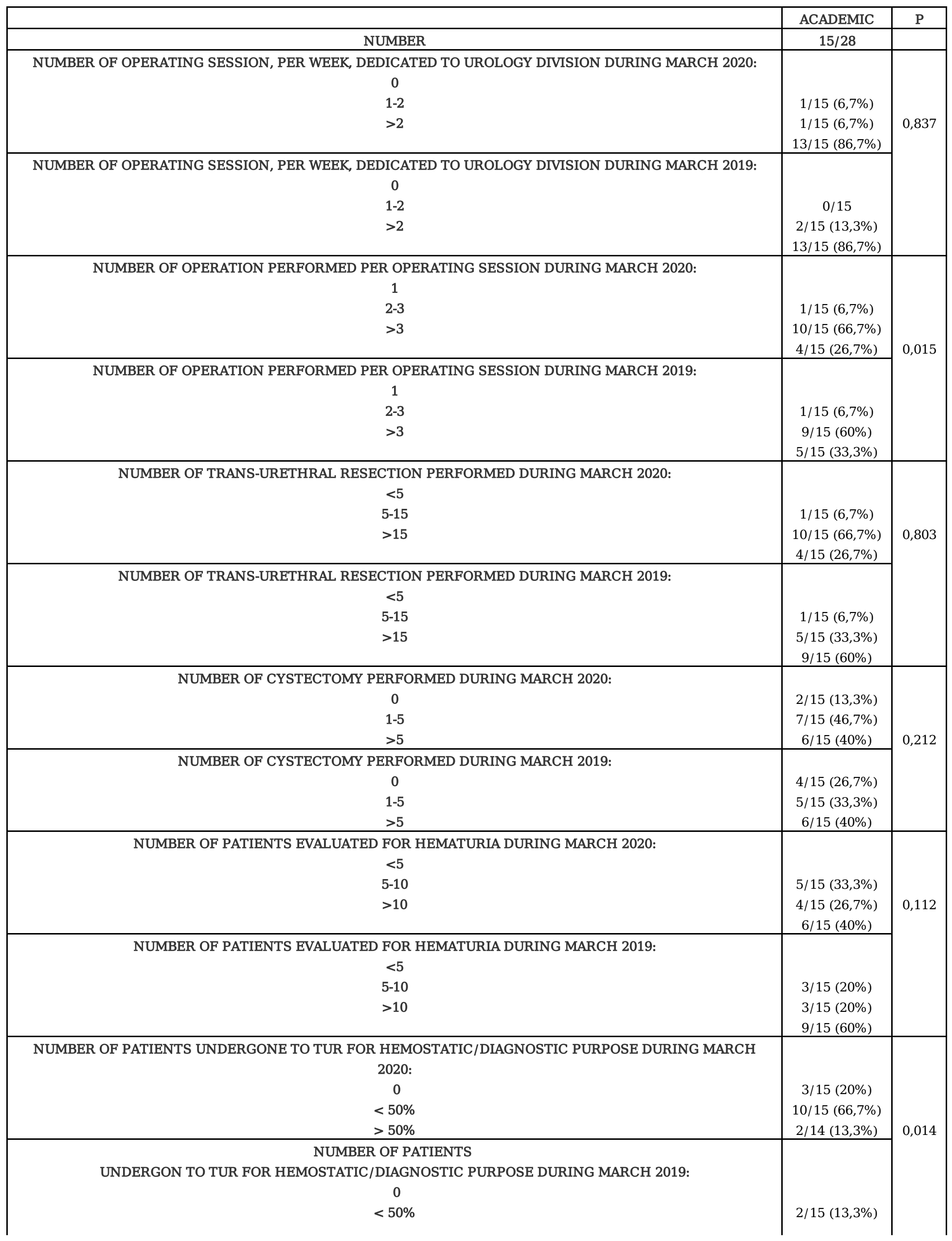

Page $18 / 29$ 
TABLE 3. Non-Academic Centers: comparison of 2019 and 2020 activity 


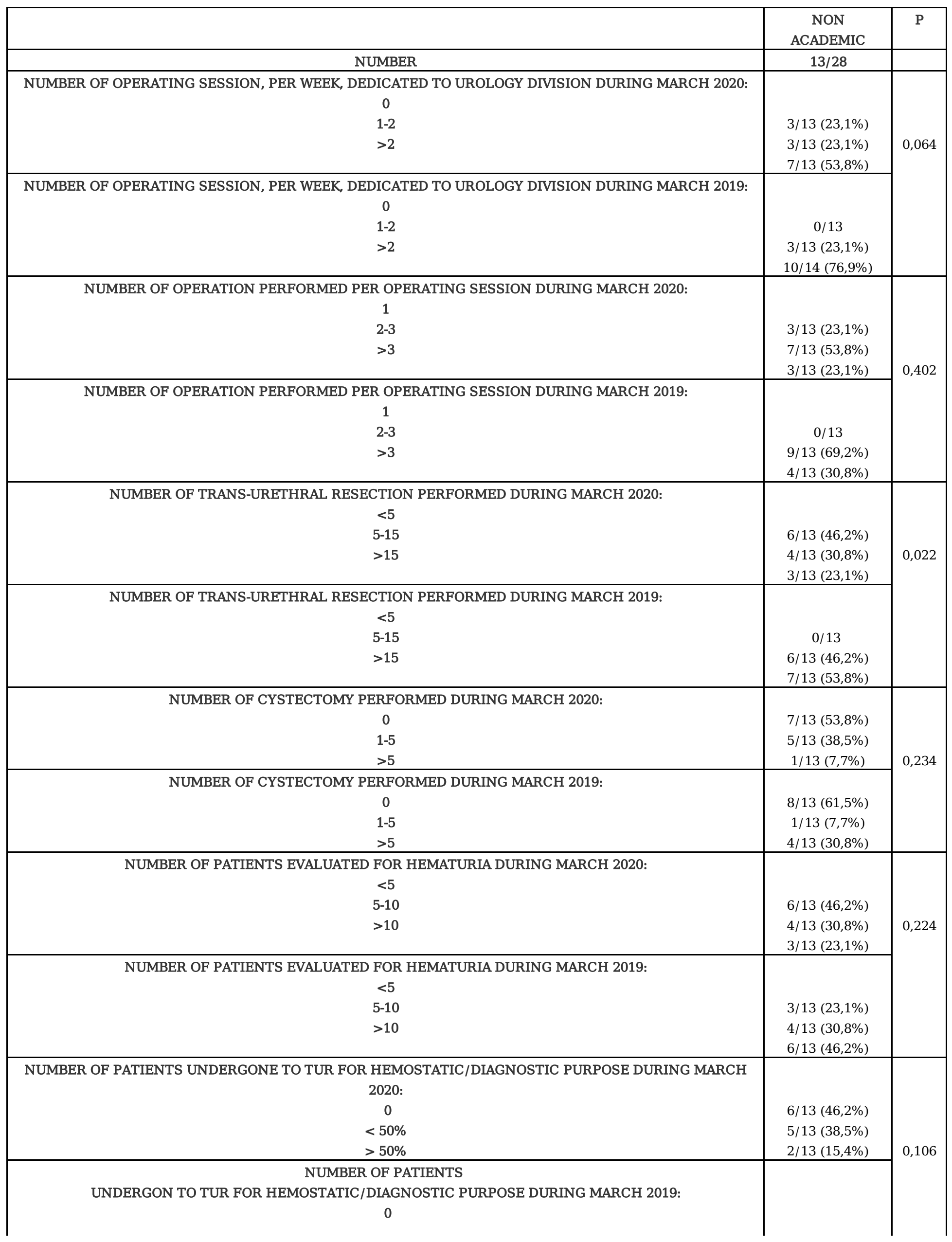


TABLE 4. Covid- and Non-Covid Centers: Comparison Of 2020 Activity 


\begin{tabular}{|c|c|c|c|c|}
\hline & COVID & $\begin{array}{c}\text { NON } \\
\text { COVID }\end{array}$ & Number & $\mathbf{P}$ \\
\hline NUMBER & $\begin{array}{c}24 / 28 \\
(85,7 \%)\end{array}$ & $\begin{array}{c}4 / 28 \\
(14,3 \%) \\
\end{array}$ & & \\
\hline $\begin{array}{l}\text { ACADEMIC } \\
\text { YES } \\
\text { NO }\end{array}$ & $\begin{array}{c}13 / 24 \\
(54,2 \%) \\
11 / 24 \\
(45,8 \%) \\
\end{array}$ & $\begin{array}{l}2 / 4(50 \%) \\
2 / 4(50 \%)\end{array}$ & $\begin{array}{l}15 / 28 \\
13 / 28\end{array}$ & 0,877 \\
\hline $\begin{array}{c}\text { EMERGENCY ROOM: } \\
\text { YES } \\
\text { NO }\end{array}$ & $\begin{array}{c}23 / 24 \\
(95,8 \%) \\
1 / 24 \\
(4,2 \%) \\
\end{array}$ & $\begin{array}{l}1 / 4(75 \%) \\
3 / 4(25 \%)\end{array}$ & $\begin{array}{c}24 / 28 \\
(85,7 \%) \\
4 / 28 \\
(14,3 \%) \\
\end{array}$ & 0,000 \\
\hline $\begin{array}{l}\text { STAFF: } \\
<10 \\
10-20 \\
>20\end{array}$ & $\begin{array}{c}8 / 24 \\
(33,3 \%) \\
10 / 24 \\
(41,7 \%) \\
6 / 24 \\
(25 \%) \\
\end{array}$ & $\begin{array}{l}2 / 4(50 \%) \\
1 / 4(25 \%) \\
1 / 4(25 \%)\end{array}$ & $\begin{array}{c}10 / 28 \\
(35,7 \%) \\
11 / 28 \\
(39,3 \%) \\
7 / 28 \\
(25 \%) \\
\end{array}$ & 0,775 \\
\hline $\begin{array}{l}\text { MEDICAL DOCTORS EMPLOYED IN COVID WARDS DURING MARCH 2020: } \\
\qquad \begin{array}{c}<30 \% \\
30 \%-50 \% \\
>50 \%\end{array}\end{array}$ & $\begin{array}{c}18 / 24 \\
(75 \%) \\
3 / 24 \\
(12,5 \%) \\
3 / 24 \\
(12,5 \%) \\
\end{array}$ & $\begin{array}{l}0 \\
0 \\
0\end{array}$ & $\begin{array}{c}22 / 28 \\
(78,6 \%) \\
3 / 28 \\
(10,7 \%) \\
3 / 28 \\
(10,7 \%) \\
\end{array}$ & \\
\hline $\begin{array}{l}\text { NUMBER OF OPERATING SESSION, PER WEEK, DEDICATED TO UROLOGY DIVISION } \\
\text { DURING MARCH 2020: } \\
0 \\
1-2 \\
>2\end{array}$ & $\begin{array}{c} \\
\\
\\
\\
4 / 24 \\
(16,7 \%) \\
4 / 24 \\
(16,7 \%) \\
16 / 24 \\
(66,7 \%) \\
\end{array}$ & $\begin{array}{l}0 / 4 \\
0 / 4 \\
4 / 4\end{array}$ & $\begin{array}{c}4 / 28 \\
(14,3 \%) \\
4 / 28 \\
(14,3 \%) \\
20 / 28 \\
(71,4 \%)\end{array}$ & 0,393 \\
\hline $\begin{array}{l}\text { NUMBER OF OPERATING SESSION, PER WEEK, DEDICATED TO UROLOGY DIVISION } \\
\text { DURING MARCH 2019: } \\
0 \\
1-2 \\
>2\end{array}$ & $\begin{array}{c} \\
\\
\\
\\
0 / 24 \\
5 / 24 \\
(20,8 \%) \\
19 / 24 \\
(79,2 \%) \\
\end{array}$ & $\begin{array}{l}0 / 4 \\
0 / 4 \\
4 / 4\end{array}$ & $\begin{array}{c}0 / 28 \\
5 / 28 \\
(17,9 \%) \\
23 / 28 \\
(82,1 \%) \\
\end{array}$ & 0,314 \\
\hline $\begin{array}{c}\text { NUMBER OF OPERATION PERFORMED PER OPERATING SESSION DURING MARCH 2020: } \\
1 \\
2-3 \\
>3\end{array}$ & $\begin{array}{c} \\
\\
\\
4 / 24 \\
(16,7 \%) \\
17 / 24 \\
(70,8 \%)\end{array}$ & $\begin{array}{l}0 / 4 \\
0 / 4 \\
4 / 4\end{array}$ & $\begin{array}{c}4 / 28 \\
(14,3 \%) \\
17 / 28 \\
(60,7 \%)\end{array}$ & 0,001 \\
\hline
\end{tabular}




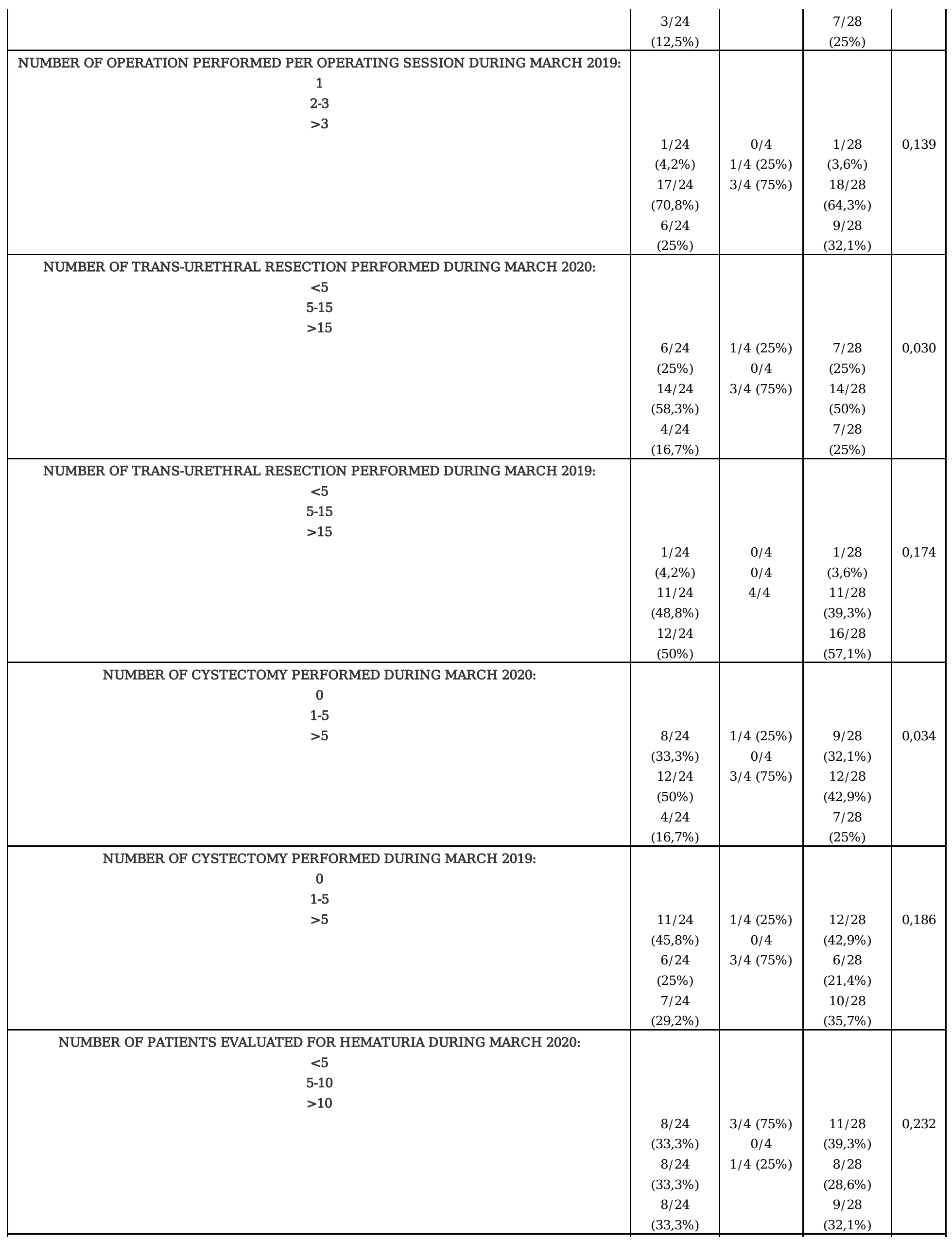




\begin{tabular}{|c|c|c|c|c|}
\hline 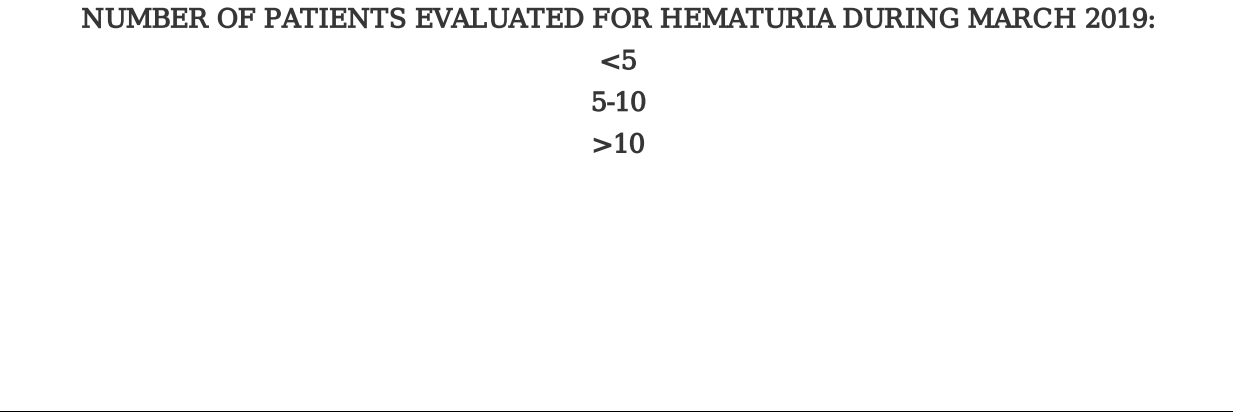 & $\begin{array}{l}3 / 24 \\
(12,5 \%) \\
7 / 24 \\
(29,2 \%) \\
14 / 24 \\
(58,3 \%)\end{array}$ & $\begin{array}{c}3 / 4(75 \%) \\
0 / 4 \\
1 / 4(25 \%)\end{array}$ & $\begin{array}{c}6 / 28 \\
(21,4 \%) \\
7 / 28 \\
(25 \%) \\
15 / 28 \\
(53,6 \%)\end{array}$ & 0,017 \\
\hline $\begin{array}{l}\text { NUMBER OF PATIENTS UNDERGONE TO TUR FOR HEMOSTATIC/DIAGNOSTIC } \\
\text { PURPOSE DURING MARCH 2020: } \\
0 \\
<50 \% \\
>50 \%\end{array}$ & $\begin{array}{c}6 / 24 \\
(25 \%) \\
15 / 24 \\
(62,5 \%) \\
3 / 24 \\
(12,5 \%)\end{array}$ & $\begin{array}{c}3 / 4(75 \%) \\
0 / 4 \\
1 / 4(25 \%)\end{array}$ & $\begin{array}{c}9 / 28 \\
(32,1 \%) \\
15 / 28 \\
(53,6 \%) \\
4 / 28 \\
(14,3 \%)\end{array}$ & 0,063 \\
\hline $\begin{array}{c}\text { NUMBER OF PATIENTS } \\
\text { UNDERGON TO TUR FOR HEMOSTATIC/DIAGNOSTIC PURPOSE DURING MARCH 2019: } \\
0 \\
<50 \% \\
>50 \%\end{array}$ & $\begin{array}{c}2 / 24 \\
(8,3 \%) \\
14 / 24 \\
(58,3 \%) \\
8 / 24 \\
(33,3 \%)\end{array}$ & $\begin{array}{c}3 / 4(75 \%) \\
0 / 4 \\
1 / 4(25 \%)\end{array}$ & $\begin{array}{c}5 / 28 \\
(17,9 \%) \\
14 / 28 \\
(50 \%) \\
9 / 28 \\
(32,1 \%)\end{array}$ & 0,004 \\
\hline
\end{tabular}

TABLE 5. International Scientific Societies recommendations about surgical management of BC during pandemic 


\begin{tabular}{|c|c|c|}
\hline SCIENTIFIC SOCIETY & TURBT & CYSTECTOMY \\
\hline $\begin{array}{l}\text { Italian Society of Urology (SIU) } \\
\text { (https://www.siu.it) }\end{array}$ & $\begin{array}{l}\text { Low priority (deferrable) } \\
\quad \square \text { TURBT after instillations } \\
\quad \square \text { TURBT in low risk pts for progression } \\
\text { Intermediate priority } \\
\text { TURBT in pts with small recurrences } \\
\text { High priority: } \\
\quad \square \text { Pts with high risk of progression } \\
\square 2^{\text {nd }} \text { look TURBT for HG or T1 }\end{array}$ & Never postpone \\
\hline $\begin{array}{l}\text { European Association of Urology (EAU) } \\
\text { (https:/ / uroweb.org/wp-content/uploads/EAU-Guidelines-Office- } \\
\text { Rapid-Reaction-Group-An-organisation-wide-collaborative-effort- } \\
\text { to-adapt-the-EAU-guidelines-recommendations-to-the-COVID-19- } \\
\text { era.pdf) }\end{array}$ & $\begin{array}{l}\text { Low priority (defer by } 6 \text { months): } \\
\square \text { Small papillary recurrences (< } 1 \mathrm{~cm} \text { ) and } \\
\text { history of Ta/ } 1 \text { low grade tumour ; } \\
\square \text { 2nd TURBT in pts with visibly complete } \\
\text { initial TURBT of T1 lesion with muscle in the } \\
\text { specimen. } \\
\text { Intermediate priority (treat before end of } 3 \\
\text { months): } \\
\text { Any primary tumour or recurrent papillary } \\
\text { tumour > 1cm and without hematuria or without } \\
\text { history of HG NMIBC } \\
\text { multiple T1HG at initial resection without } \\
\text { muscle in the specimen } \\
\text { tumo }\end{array}$ & $\begin{array}{l}\text { Cystectomy has to be } \\
\text { performed within } 3 \\
\text { months since the } \\
\text { diagnosis in case of: } \\
\square \text { pts with highest } \\
\text { risk NMIBC; } \\
\square \text { pts with BCG } \\
\text { unresponsive tumor } \\
\text { or BCG failure. }\end{array}$ \\
\hline $\begin{array}{l}\text { National Comprehensive Cancer Network (NCCN) } \\
\text { (https://www.nccn.org/covid- } \\
\text { 19/pdf/Cancer_Services_Patient_ } \\
\text { Prioritization_Guidelines.pdf) }\end{array}$ & $\begin{array}{l}\text { Possible postponing of low risk pts } \\
\text { Not posponing high risk pts }\end{array}$ & \\
\hline $\begin{array}{l}\text { American Urological Association } \\
\text { (https://www.facs.org/covid-19/clinical-guidance/triage). }\end{array}$ & $\begin{array}{l}\text { High risk: } \\
\text { TURBT as scheduled } \\
\text { Not- high risk: } \\
\text { Postpone in 4-12 weeks }\end{array}$ & $\begin{array}{l}\text { High risk cancer: } \\
\text { Cystectomy as } \\
\text { scheduled } \\
\text { Not- high risk cancer: }\end{array}$ \\
\hline
\end{tabular}


TABLE 6. General principles of surgical management during pandemic 


\section{ALL PATIENTS}

Prescreen and screen for COVID-19 symptoms via telephone calls or digital platforms

In the clinic, symptomatic pts are diverted to a separate secondary screening area for consideration for COVID-19 testing

All pts has to potentially affected by COVID-19 until they do not execute:

๑ laboratory test

Brucher 2020

$\square$ naso-pharyngeal swab

$\square$ chest examination (X-Ray/CT)

All the pts has to be clinically stratified before any surgical procedures, evaluating the pre-hospital health status and comorbidities. Clinicians can use various scoring systems and or calculators (ASA-PS, CCI, SRS and others)

Rationing care: conflict between the greater social good and channeling a large amount

of resources for an individual

patient, even with worse prognosis per se, according to pandemic evolution.

PATIENTS WITH COVID 19

Isolation rooms and cautions manipulating body fluids and all medical items

Puliatti

COVID-19 pneumonia carries a high mortality rate especially during peri- and post-

operative times

\section{CANCER PATIENTS}

Increasing the use of PPE for pts and relatives.

Considering the increased risk of contracting and developing complications from COVID19.

Liang W.Lancet Oncol 2020

Yu J JAMA Oncol 2020

HEALTH CARE STAFF

General preventive measures followed by all staff

BRUCHER

UEDA JNCCN 2020

Cinar JNCCN 2020

The positioning and removal of PPE must be performed according to WHO and Centre (https://www.cdc.gov)

for Disease Control and Prevention (CDC) guidelines

Centralized resource or website to communicate the recommendations to the healthcare

UEDA JNCCN 2020 workers as guidelines around PPE and workflows change

Cinar JNCCN 2020

Telecommute when possible, with limited onsite staff participating in rotations on a daily

CINNAR basis

Establish clear stay-at-home and return-to-work guidelines

Resources for wellness and stress management for healthcare workers

Reassignment of clinical duties to administrative roles should be considered for staff who are immunocompromised or have significant comorbidities

CINNAR

CINNAR

(UEDA NCCN 2020)

(UEDA JCCN 2020). 
that put them at increased risk with COVID-19.

\section{SURGERY}

Surgery in general is at higher risk for transmission of respiratory infections.

Leonardi 2020

Considering the concrete possibility of viral contamination of OR personnel during surgery

Surgical staff should not stay in the OR during intubation maneuvers, waiting a few minutes from their conclusion before entering, leaving any infected droplets to settle Intubation and extubation to take place inside a negative pressure room

(https://www.asahq.org/in-the-

spotlight/coronavirus-covid-

19-information) (1, 2).

Limiting surgery to life-threatening disease to minimize the use of pts beds, ICU beds, ventilators, antiseptic foaming and PPE

Limit surgeries and procedures to only essential, urgent, or emergent cases

Complex surgery can be deferred according to patient status, hospital infrastructure and actual local COVID-19 burden.

Adopting standardized surgical technique in order to reduce the OR time and the risk of

Leonatdi 2020 postoperative complications

Implementation of team of surgeons who share the same OR and anesthesiologists.

Procedures should be performed by expert surgeon, outside the learning curve

Reduce to minimum the personnel required to perform the operation

Ueda JNCCN 2020

Minimize the surgical trauma as much as possible

Measures to reduce aerosolization in the OR should be considered (closed circuits, insufflators continuous cycle, fume extraction).

Blood product shortages due to decline in community blood drives necessitate stricter adherence to and considering lower thresholds for transfusion.

COVID-19 Response Tools: Seattle Cancer Care

https://www.seattlecca.org/covid-19-screeningtools. Accessed

March 16, 2020.

Ueda JNCCN 2020

\section{LAPAROTOMY}

According to Chinese experience favoring laparotomy due to the characteristics of surgical smoke, both chemical and infectious

\section{LAPAROSCOPY}

Specific caution during handling bowel or with trans-peritoneal approach because the remission of viruses through carbon dioxide. The use of devices to filter $\mathrm{CO} 2$ should be strongly considered.
Ficara e 9 e 10 in Ficarra)

Leonardi 2020

https://siceitalia.com/covid19/

https:// eaes.eu/eaesand-sages-recommendationsregarding-surgical-response-to-covid-19-crisis/

Leonardi 2020 


\begin{tabular}{|l|l|} 
Programming electrosurgical units and lasers to the lowest possible settings & Leonardi 2002 +9-15 in Lei \\
\hline $\begin{array}{l}\text { Quicker discharge of pts following laparoscopy, with lower incidence of wound } \\
\text { infections. }\end{array}$ & \\
\hline \multicolumn{2}{|c|}{ ALTERNATIVE TO SURGERY } \\
\hline Favoring a non surgical approach, if justifiable & Ueda JNCCN 2020 \\
\hline Enrollment in clinical trials has to be limited too those are most likely to benefit the pts
\end{tabular}

\section{TABLE 7. Organizational and functioning criteria for CFC}

\begin{tabular}{|c|c|c|}
\hline \multirow{4}{*}{ 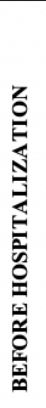 } & ITEM & CRITERIA \\
\hline & Triage & $\begin{array}{l}\text { Triage for possible COVID-19 symptoms by telephone at } \\
\text { home }\end{array}$ \\
\hline & Role of swab & $\begin{array}{l}\text { Diagnostic swab for Covid-19 executed to all staff members and to } \\
\text { patients before the beginning of healthcare activity }\end{array}$ \\
\hline & & $\begin{array}{l}\text { Repetition of swab (or faster and less expensive test in the future) every } \\
\text { two weeks in order to avoid the risk of contamination of pts during the } \\
\text { process of care. }\end{array}$ \\
\hline \multirow{6}{*}{ 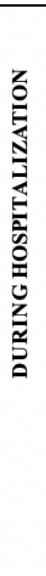 } & PPE & $\begin{array}{l}\text { Protect the patient from potential Covid infections in the hospital setting. } \\
\text { PPE for medical and nursing staff: gloves, FFP2 mask, plus surgical } \\
\text { masks, if the former are equipped with an exhalation valve, waterproof } \\
\text { gown for contacts, protective visor. }\end{array}$ \\
\hline & \multirow[t]{4}{*}{ Room } & No one admitted into the ward except the pts \\
\hline & & Single room with personal bathroom. \\
\hline & & Food waste must be handled as special hazardous waste \\
\hline & & Room must undergo sanitization at the end of the stay \\
\hline & \multirow[t]{3}{*}{ Patients } & $\begin{array}{l}\text { During hospital stay patients should be provided with as } \\
\text { many instructions as possible to facilitate their return to, } \\
\text { and stay at, home. }\end{array}$ \\
\hline \multirow{2}{*}{ 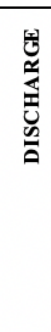 } & & $\begin{array}{l}\text { Patients should be discharged under stable good } \\
\text { conditions in order to minimize the risk of readmission. }\end{array}$ \\
\hline & & $\begin{array}{l}\text { It is advisable to reduce or reschedule post-discharge } \\
\text { controls and implement an adequate system of } \\
\text { communication for telemonitoring discharged patients in } \\
\text { order to reduce hospital visits. }\end{array}$ \\
\hline
\end{tabular}

